 \\ Journal of Personal Selling \& Sales Management
}

\section{Does it pay to be proactive? Testing proactiveness and the joint effect of internal and external collaboration on key account manager performance}

\author{
Lesley E. Murphy \& Joseph P. Coughlan
}

To cite this article: Lesley E. Murphy \& Joseph P. Coughlan (2018) Does it pay to be proactive? Testing proactiveness and the joint effect of internal and external collaboration on key account manager performance, Journal of Personal Selling \& Sales Management, 38:2, 205-219, DOI: 10.1080/08853134.2018.1437352

To link to this article: https://doi.org/10.1080/08853134.2018.1437352

曲 Published online: 08 Mar 2018.

Submit your article to this journal $₫$

Џلll Article views: 305

View Crossmark data ¿

Citing articles: 1 View citing articles $\square$ 


\title{
Does it pay to be proactive? Testing proactiveness and the joint effect of internal and external collaboration on key account manager performance
}

\author{
Lesley E. Murphy ${ }^{\mathrm{a}}$ and Joseph P. Coughlan ${ }^{\mathrm{b}}$ \\ ${ }^{a}$ School of Marketing, Dublin Institute of Technology, Aungier Street, Dublin, Ireland; ${ }^{b}$ School of Business, Maynooth University, \\ Maynooth, Kildare, Ireland
}

(Received 15 May 2017; accepted 1 February 2018)

\begin{abstract}
In a survey of key account managers, we examine how internal and external collaboration individually and jointly affect performance. We shed light on the role of proactiveness in generating these effects. Using a social exchange theory lens, we consider how managing a portfolio of relationships through collaboration, both inside and outside of the organization, plays an important role in key account manager performance. Using data collected from key account managers across a range of industries, this study finds that proactive key account managers have higher levels of collaboration and performance. We find however that only the joint effect of internal and external collaboration positively affects performance. Interestingly, there were no direct effects. This study extends our understanding of the nature of collaboration in business-to-business relationships. Drawing on these findings, we discuss several theoretical and managerial implications.
\end{abstract}

Keywords: internal collaboration; external collaboration; proactiveness; key account management; social exchange theory; interaction effect

Given uncertain work environments and rising workplace complexity, it is increasingly important for employees to take advantage of available opportunities, organize themselves to work effectively, and be more innovative (Spitzmuller et al. 2015; Zhang, Wang, and Shi 2012). One way to achieve this aim is through collaboration. Collaboration has been a focus of academic attention across a number of disciplines, including supply chain management (Cai, Jun, and Yang 2017; Kim and Lee 2010; Min et al. 2005), marketing (Ellinger 2000; Spekman, Salmond, and Lambe 1997), and management (Ang 2008; Singh and Mitchell 2005). Collaboration is important for a number of reasons. It motivates partners to be engaged in achieving common goals (Mentzer et al. 2001), and it enhances learning and knowledge development (Kim and Lee 2010). Collaboration does not require that two groups are merged or that their activities are integrated into a single function, but rather refers to the ability of two separate groups to align their activities, communicate across boundaries, and create common goals (De Luca and Atuahene-Gima 2007; Kahn 1996; Le Meunier-FitzHugh and Lane 2009). Furthermore, customers are now more demanding, requiring higher degrees of collaboration with their producers to meet their needs (Smirnova et al. 2011). Strong levels of collaboration lead to better communication, higher levels of stability, and a reduction of both conflict and opportunism between parties (Bucklin and Sengupta 1993;
Spekman and Carraway 2006). However, there are two key challenges to operationalizing collaboration: first, the question of with whom to collaborate, and second, knowing how to enable increased collaboration.

Despite the array of literature on collaboration, there is little consistent advice on choice of collaborative partners. The evidence seems to suggest that collaboration with everyone is beneficial in some way (Cai, Jun, and Yang 2017; Georges and Eggert 2003; Le Meunier-FitzHugh and Lane 2009; Ryals and Knox 2001; Smirnova et al. 2011; Speakman and Ryals 2012) as part of a portfolio of relationships (Plouffe et al. 2016). Given the pressures on organizations, collaboration with every possible partner to the same level is not feasible, so a choice must be made as to the level of relationship with each partner. Relationships have become an increasingly important way of securing business partners and guarding against business risk (Homburg, Workman, and Jensen 2000; Morgan and Hunt 1994), as well as gaining competitive advantage (Hunt 1997). Some partners are key to firm success, and many organizations devote specific resources to important customers to reap the benefits collaborative relationships bring. These customers, often known as key accounts (Davies and Ryals 2013; Guenzi, Georges, and Pardo 2009; Workman, Homburg, and Jensen 2003), merit significant attention from the selling organization due to their size or strategic importance. Typically, key account 
managers have the challenging task to deploy specific human resources (Boles, Johnston, and Gardner 1999; Ryals and Rogers 2007) to answer to the needs of both their customers and their organization. To succeed, key account managers need to have strong collaboration skills, both within the organization and with their key accounts.

This article focuses on internal and external collaboration within a key account management context and tests their individual and joint effects on performance. In addition to the focus of with whom to collaborate, this study concentrates on personality traits that may drive collaboration. One potential characteristic, tested in this research, is for employees to be proactive (Crant 2000; Wu et al. 2018). Bateman and Crant (1993) introduced the concept of a proactive personality to organizational research. An individual with a proactive personality is someone "who is relatively unconstrained by situational forces and who effects environmental change" (Crant 1995, 532). Proactive employees attempt to affect what happens in their lives and do not just let life happen to them (Grant and Ashford 2008). In this article, for consistency, we use the term "proactiveness" as the nomenclature on the concept differs between authors. Proactiveness has been studied in the sales domain (Barrick and Mount 1991; Mallin, Ragland, and Finkle 2014; Pitt, Ewing, and Berthon 2002), where it has been found to be a small, but significant, predictor of the quality of a salesperson as rated by his or her manager (Pitt, Ewing, and Berthon 2002).

To address this managerial issue, we explore how the proactiveness of key account managers affects their engagement in collaborative activities both internally, with colleagues, and externally, with customers. Specifically, we develop and test a model that explores associations between proactiveness, internal and external collaboration, and performance. We contribute to the literature in two distinct ways. First, we explore how key account managers with higher levels of proactiveness may have higher levels of internal collaboration, external collaboration, and performance. Second, we not only investigate the individual effects of internal and external collaboration on performance, but also consider how the two forms of collaboration may have a joint effect on performance. We contribute to the literature by providing insights to scholars and organizations on the importance of individual attributes of the key account managers in building buyer-supplier relationships.

\section{Theory}

An emerging stream of research integrates key account management and relationship marketing theory, where organizations want to build long-term collaborative relationships with their strategically important customers (Guenzi, Georges, and Pardo 2009; Sengupta, Krapfel, and Pusateri 2000; Tzempelikos and Gounaris 2013).
Different frameworks and theories that underpin relationship marketing have been advanced in the literature to understand collaboration. We adopt one of the most widely cited of these concepts, social exchange theory (SET), to serve as a foundation for our arguments (Cropanzano and Mitchell 2005). SET has been applied in the sales domain (Kashyap and Sivadis 2012; Lussier and Hall 2017; Ramaswami, Srinivasan, and Gorton 1997; Yen and Barnes 2011). SET emerged as theorists (Blau 1964; Emerson 1976) attempted to understand how individuals interact with each other over time (Cropanzano and Mitchell 2005). To carry out their role effectively, salespeople develop relationships with other employees (Flynn 2003) and customers (Houston, Gassenheimer, and Maskulka 1992; Sheth 1996). SET suggests that these relationships have both economic and social outcomes (Lambe et al. 2001) and that social relationships develop over time (Dwyer, Schurr, and Oh 1987; Morgan and Hunt 1994) due to repeated encounters (Lussier and Hall 2017). SET is based on the concept of reciprocity norms (Cropanzano and Mitchell 2005) that shape interactions between partners based on the expectation of giving and receiving relational benefits (Blau 1964; Lambe et al. 2001). This high level of interaction leads to interdependence, which involves mutual and complementary exchanges (Molm 1994). Key account managers are an interesting group to consider under the lens of SET as they typify the issue of interdependence, both internally within the organization and externally with customer organizations. Cropanzano and Mitchell (2005) specifically suggested considering exchange relationships outside the firm to broaden the scope of SET.

Collaboration is essential for key account managers as they play a boundary-spanning role between two or more organizations (Piercy 2009, 2010; Pardo, Salle, and Spencer 1995; Pardo et al. 2006). Key account managers are what has been termed in the literature as "orchestrators" of resources (Corcoran et al. 1995). They bring together, like a conductor in an orchestra, a diverse range of individuals and talents within the organization to provide an attractive offering for their customer. Consequently, one aspect that has emerged in the literature is how salespeople marshal the intraorganizational resources of their firm to achieve better performance (Bolander et al. 2015; Evans et al. 2012; Plouffe and Barclay 2007). Key account managers represent their customer within their own organization and acquire resources for these customers through a diverse portfolio of networks (Speakman and Ryals 2012). In addition to managing the buyer-seller relationship, the incumbents have to engage with a number of different actors within their own organization (Bolander et al. 2015) and bring together resources to perform their role (Georges and Eggert 2003; Guenzi, Georges, and Pardo 2009). This network of stakeholders, characterized as a portfolio of relationships (Plouffe et al. 
2016), has be managed by the key account manager. Key account managers translate customer requirements so that their organization can meet customer needs (Schultz and Evans 2002). The key account manager needs to work with a wide variety of internal groups, such as production, logistics, marketing, and finance (Speakman and Ryals 2012), and has to collaborate internally with other functions for four reasons. They need to work together with others in their organization first to provide value for the customer; second, to orchestrate customer-related efforts internally (Hutt 1995; Pardo, Salle, and Spencer 1995); third, to work internally to generate value for the organization; and finally, to get greater efficiencies (Henneberg et al. 2009).

Internal collaboration is core to achieving their objectives (Ryals and Knox 2001). However, the literature is remarkably silent on the drivers of these collaborative activities on the part of the individual key account manager, and there have been repeated calls for more research into the individual behaviors of key account managers (Davies and Ryals 2013; Guenzi, Georges, and Pardo 2009). It is critical to understand what may drive success in key account relationships. This is a pressing managerial issue as the interpersonal relationships that key account managers handle are critical precursors to developing higher levels of interorganizational drivers of performance, such as trust and commitment (Mavondo and Rodrigo 2001). It is clear from the literature that both internal and external collaboration are individually important for performance (Cai, Jun, and Yang 2017; Speakman and Ryals 2012), yet their joint effect is not well understood.

\section{Model and hypothesis development}

In light of the relationship-building context of the role of the key account manager, variables such as proactiveness and collaboration could reasonably be expected to influence performance. This study aims first to assess the effect of the level of key account manager proactiveness on internal and external collaboration, and ultimately on performance. Second, this article seeks to understand how internal and external collaboration affect performance, both individually and jointly. The relationships being tested are depicted in Figure 1.

Borrowing from the management literature, we identify an individual characteristic - proactiveness - that we predict will impact the success of the key account manager in terms of both their levels of internal and external collaboration and their performance. Proactive individuals directly alter environments, and their behavior is rooted in the need for people to feel that they have the ability to manipulate and control the environment (Bateman and Crant 1993). According to this perspective, proactive individuals succeed because they are able to alter their environment to bring about change and are known colloquially as being self-starters (Thomas, Whitman, and Viswesvaran 2010). Recent meta-analytic studies (Spitzmuller et al. 2015; Thomas, Whitman, and Viswesvaran 2010) suggest that being proactive is directly linked to overall job performance and to performance in individual tasks, even after controlling for standard (the Big Five) personality traits and general mental ability. Being proactive has been found to lead to both career (Seibert, Crant, and Kraimer 1999) and organizational success (Fuller and Marler 2009; Griffin, Neal, and Parker 2007).

Research findings demonstrate that proactive individuals have higher levels of organizational commitment (Den Hartog and Belschak 2007; Joo and Lim 2009), which is a key driver of strong relationships between partners (Morgan and Hunt 1994) and an important enabling constituent of greater levels of collaboration. As previously defined, proactiveness centers on the extent to which people take action to influence their environment to effect change. In a key account management context, where relationships are the method of attaining higher levels of organizational performance (Guenzi, Georges, and Pardo 2009), proactive key account managers should strive to collaborate both internally and externally to increase their performance. Smirnova et al. (2011) found that increased interaction, in a sales context, leads to higher levels of collaboration. This need for collaboration is an essential component of the key account management role, and those who are more proactive have been found to be better at implementing whatever is needed to complete their role effectively (Pitt, Ewing, and Berthon 2002). Spitzmuller et al. (2015) noted that individuals with higher levels of proactiveness tend to be more conscientious. For key account managers, this trait translates into the requirement to establish, build, and maintain relationships internally and externally through collaborative activities. Thus, it is hypothesized as follows:

H1: The higher the level of proactiveness, the higher the level of internal collaboration demonstrated by the key account manager.

$\mathrm{H} 2$ : The higher the level of proactiveness, the higher the level of external collaboration demonstrated by the key account manager.

In a modern work setting, proactiveness has been associated with increased levels of performance because it focuses on the extent to which people take action to influence their environment to effect change. In a key account manager context, this measure translates to key account managers planning ahead and taking advantage of synergistic opportunities with their customer, or mitigating against potential threats and dangers to their customer in the future, which helps to improve their 


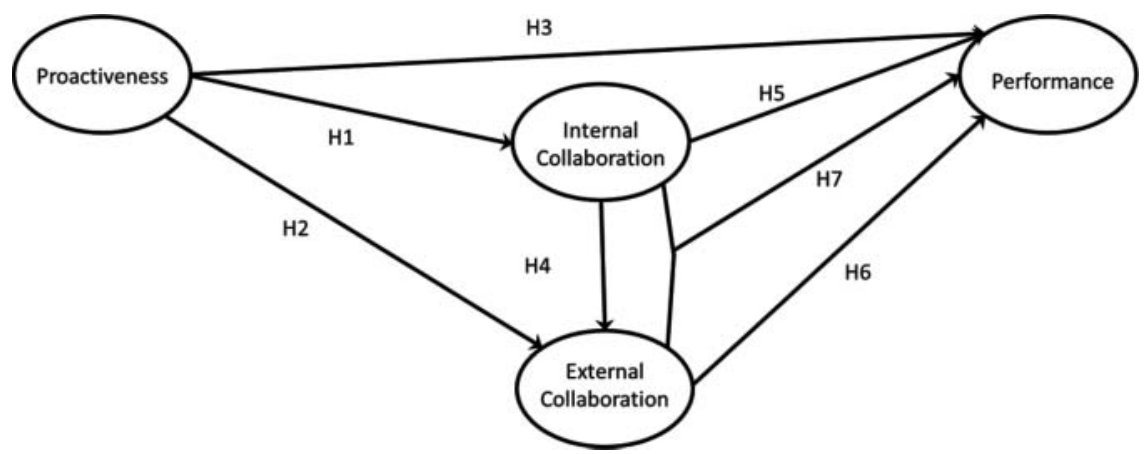

Figure 1. Conceptual model.

performance. Initial support for this contention used a sample of recent college graduates (Seibert, Crant, and Kraimer 1999; Thompson 2005), though research with other samples conducted around the same time did not find a direct relationship with either subjective or objective performance measures (Erdogan and Bauer 2005). Mallin, Ragland, and Finkle (2014), in a sales context, found a strong positive relationship between proactiveness and performance. Thus, it is hypothesized as follows:

H3: The higher the level of proactiveness, the higher the level of key account manager performance.

Empirical research in the area of collaborative activities between key account managers and their customers is relatively sparse. This is despite Pardo and colleagues' (2006) assertion that key account managers are significantly engaged in collaborative activities. Cross-functional collaboration is an intangible concept and reflects the recognition by internal functions in an organization that they are interdependent and need to work together for their mutual benefit (De Luca and Atuahene-Gima 2007). Key account managers are primarily involved in collaboration to improve the fit between their organization's value offering and the needs of their customer (Georges and Eggert 2003). This interdependence is a key concept within the SET framework (Molm 1994) and links to the rationale for the inception of SET, which focused on how individuals interact with each other. If key account managers have collaborative skills and the ability to work together with others within their own organization, it is engrained that they will naturally work together with their customer. Thus, it is hypothesized as follows:

H4: The higher the level of internal collaboration, the higher the level of external collaboration demonstrated by the key account manager.

Le Meunier-FitzHugh and Piercy (2007, 2009) highlighted a range of empirical studies that demonstrate that collaboration across functions within organizations can deliver superior customer value. The internal relationships among people, departments, and functions permit an organization to develop and implement its strategies, and these relationships need to be managed (Ritter, Wilkinson, and Johnston 2004). Using a SET lens, relationships, which include internal collaboration, have been found to have economic outcomes (Lambe et al. 2001). Cross-functional integration is seen to be critical (Spekman and Carraway 2006) for key account management success. Stank, Keller, and Daugherty (2001) found that increased internal collaboration, in a supply chain context, led to higher levels of performance. Sanders (2007) found support for the contention that internal collaboration leads to higher levels of performance. Internal collaboration is important as it enables employees in organizations to make accelerated, superior decisions, which has a positive impact on resultant actions and ultimately their performance. Thus, it is hypothesized as follows:

H5: The higher the level of internal collaboration, the higher the level of performance of the key account manager.

Jap (1999) suggests that individuals, such as key account managers, play a key role in building closer collaborations with external customers. These collaborations lead to higher levels of organizational performance and the realization of competitive advantage over time (Jap 1999). Workman, Homburg, and Jensen (2003) found support for this perspective in their study on key account manager effectiveness. This is also supported by SET, which shows that relationships have economic outcomes. Ulaga and Eggert (2006) demonstrate that the benefits accruing from a relationship with a partner play a stronger role than cost-reduction initiatives in differentiating a firm from its competitors. Spekman and Carraway (2006) found that cross-boundary integration is important for key account management success. Collaborating with a customer means that a key account manager understands what the priorities of the relationship are and is able to 
work together with the customer to solve problems, which helps improve performance. Thus, it is hypothesized as follows:

H6: The higher the level of external collaboration, the higher the level of performance of the key account manager.

The literature on intraorganizational interfaces examines the fact that functions within an organization need to work together to deliver value to the customer, which implies that interfunctional collaboration is a key prerequisite to the delivery of customer value (Hughes, Le Bon, and Malshe 2012). When a key account manager engages in internal collaboration - an essential part of the role (Henneberg et al. 2009; Pardo et al. 2006) - it leads to increased customer commitment as the customer can see the positive outcomes of internal collaboration, such as faster new product development and more process efficiencies. This commitment has positive consequences for performance. Stank, Keller, and Daugherty (2001) found that internal and external collaboration were highly correlated. Zhou, Hong, and Liu (2013) found that internal cohesiveness, which is similar to our conceptualization of collaboration, has a joint effect with external collaboration on performance in the human resource management context. Organizations with enhanced internal relationships provide superior value to the customer, and the goal of an organization to create customer value is dependent on the synergistic coordination of many parts of the organization, where internal resources are effectively harnessed to assemble a value proposition for the external customer and create a competitive advantage (Goold and Campbell 1998; Hughes, Le Bon, and Malshe 2012). Having both internal and external collaboration operating at high levels is core to attaining high levels of performanceknowledge sharing, and joint planning leads to better decisions, which then has a positive impact on performance. Thus, it is hypothesized as follows:

H7: Internal and external collaboration have a joint effect on key account manager performance, with higher levels of both forms of collaboration leading to higher levels of performance.

\section{Research methodology \\ Questionnaire development}

Prior to the implementation of this study, a series of 10 interviews with key account managers from a range of organizations and industrial sectors was undertaken. Interviews took place over a three-month period. Key account managers were interviewed about their on-the-job experiences, their role both inside and outside the organization, and the necessary attributes for a key account manager to be successful. The outcome of this phase demonstrated that being proactive was important for collaboration both internally, within the organization, and externally, with customers. The collaborative nature of the key account manager role came through strongly, with one respondent stating that they were "at the coalface, trying to get your customer to trust you, but at the same time trying to influence people internally so [you] can get your job done and perform."

The survey employed a 7-point Likert scale. Proactiveness was originally operationalized as a 17 -item scale (Bateman and Crant 1993). However, for reasons of parsimony, an abridged version of the scale was used, which was adopted from a subsequent study by Seibert, Crant, and Kraimer (1999) and demonstrated high levels of reliability in other studies (Yang et al. 2017; Zhang, Wang, and Shi 2012). Collaboration items were taken from Ellinger (2000) and adapted into two scales: one to measure internal collaboration and one to measure external collaboration. Respondents were instructed to consider their work with internal members of their own organization for internal collaboration and to consider their key account customer for the external collaboration measure. Items to measure the performance of the key account manager were taken from Flaherty and Pappas (2009).

To assess content validity, once the questionnaire was developed, it was peer reviewed by three subject-matter experts, who had undergone the process of survey development and analysis previously, following Denscombe's (2003) recommendations. The feedback received was used to redraft the survey as some items were misunderstood because the scales had been previously developed and tested outside Ireland. The questionnaire was pretested by a cohort of 25 executive MBA students, following Froehle and Roth (2004). This group was chosen due to their high level of commercial acumen and their understanding of the importance of strategically managing customers. This pretest was carried out to ensure that clarity was obtained and that all relevant questions (and no irrelevant questions) were included in the survey. Analysis of the pretest showed no significant reliability or validity issues.

\section{Sample}

Gaining access to a population of key account managers is challenging as many organizations do not have large cadres of such employees, given their specialized roles with important customers. This particular strategic role with customers makes key account managers difficult to find and relatively scarce in individual organizations. The problem of locating sufficient numbers of relevant respondents is widely recognized in this area, and previous studies have used convenience samples to overcome this issue of access (Guenzi, Georges, and Pardo 2009). 
To directly access key account managers, a list consisting of a commercial database containing details of sales directors in conjunction with a published list of the top 1,000 firms in Ireland at that time was generated. The sales directors of all these firms were contacted for the contact details of their key account managers. This resulted in a population of 1,246 key account managers. These details were verified, where possible, using the professional networking site LinkedIn.

The survey respondents were all key account managers, which is a similar approach adopted in recent studies in the area of key account management (Guenzi, Georges, and Pardo 2009; Guenzi, Pardo, and Georges 2007; Schultz and Evans 2002; Sengupta, Krapfel, and Pusateri 2000). The mean age of respondents was 40 years, with the majority of the sample $(46 \%)$ in the 35- to 44-year age bracket. Respondents were also asked about their experience level (i.e., the number of years they have been working in this role). The majority of respondents in this survey (89\%) had over 10 years of industry experience and, on average, they had been working for their company for 9.50 years and in their role, as key account manager, for 4.60 years. This is comparable to previous studies in the key account management area (Guenzi, Georges, and Pardo 2009). Given the importance of personal characteristics on performance and the nature of this study, the gender and age of the key account managers were included in the model as control variables. Demographic variables, such as age and gender, have been shown to influence customer evaluations and impressions (McColl and Truong 2013; Pinar and Hardin 2006). The recent meta-analysis on proactiveness (Spitzmuller et al. 2015) showed that there were no gender effects, but they did not test for age effects. The number of accounts that a key account manager is responsible for is also posited as a control variable, in that the higher the number of accounts managed, the less opportunity the key account manager has to be proactive, and to collaborate internally and externally, which may also have an impact on performance. Guenzi, Pardo, and Georges (2007) controlled for number of accounts to see whether there were any differences between key account managers with a large versus small number of accounts. By controlling for these variables, a stronger test of the theoretical model is provided.

Self-report methodologies - in particular, the written survey - have been utilized as the primary method of data collection in a substantial number of previous studies. Schultz and Evans (2002) contend that it is appropriate to use the key account managers' selfreport assessments as a proxy interpretation of the view of the key account, given that, in such close, long-term relationships, the understanding parties have of each other transcends the typical information available in single buyer-seller transactions. In addition, Schultz and Evans (2002) surveyed 40 key accounts in their study and concluded that the customer survey generated practically identical relationship results to those of the vendor data.

In all, 1,246 surveys were distributed, with an option to fill in online or via paper, and 232 surveys were completed in total. Sixty-three surveys were completed by respondents online, and 168 were returned by mail, which gave a total survey response rate of $18.6 \%$. Although previous studies in the area of relationship marketing and key account management have yielded considerably higher response rates (Guenzi, Georges, and Pardo 2009), this is perhaps because they targeted a convenience sample. Mavondo and Rodrigo (2001) recorded a response rate of 28\%, while Morgan and Hunt's (1994) survey yielded a response rate of $14.6 \%$. Therefore, the response rate for this study falls into the parameters of previous surveys adopting a similar sampling technique. Respondents were asked only to complete the questionnaire if they were responsible for the relationship between their firm and a company being classed as strategic to the future of their firm. Of the completed surveys, two were excluded immediately because the respondents specified that they were not key account managers. The individual surveys were then reviewed for completeness, and the final number of valid surveys included in the sample, following a detailed data-cleaning process, was 150 . The model as depicted in Figure 1 was tested using structural equation modeling following the two-stage approach of Anderson and Gerbing (1988).

To reduce common method bias within this research (Podsakoff et al. 2003; Podsakoff, MacKenzie, and Podsakoff 2012), established scales of high quality were used and proximal separation was employed. Many of the respondents asked for further information on the findings, showing further evidence of risk mitigation. However, it is still important to test for bias, so the marker variable method was used (Hulland, Baumgartner, and Smith 2017; Lindell and Whitney 2001). The complexity of the key account relationship was used as a marker variable. As per Lindell and Whitney (2001), a discounted correlation matrix was created. The guidelines suggest that common method variance does not pose a major threat to interpretation of the results when correlations in the discounted correlation table do not lose significance or change signs (Lindell and Whitney 2001; Williams, Hartman, and Cavazotte 2010). The highest difference was 0.04 , which did not change the directionality or the significance of any of the interconstruct correlations. To assess potential late-response bias, early and late responders were compared on the size of their firm (Armstrong and Overton 1977). No significant differences were found across the two groups using $t$-tests. The method of 
administration, online or hard copy, was also tested, and no significant differences were found using $t$-tests.

\section{Reliability}

Confirmatory factor analysis (CFA) using MPlus 8 was completed to establish convergent validity. Items with low reliabilities and loadings were removed. Table 1 shows the means, standard deviations, loadings, and reliability estimates (composite reliability $[\mathrm{CR}]$ and average variance extracted [AVE]) for all measures retained for the final analysis. A measurement model was specified for the constructs with no causal relationships, and free covariance estimation between constructs was developed, showing an acceptable level of fit $\left(\chi^{2}=688.817\right.$, df $=318, p=.000$, CFI $=0.893$, RMSEA [root mean squared error of approximation] = 0.085, SRMR [standardized root mean square residual] $=0.062$ ). Further evidence of convergent validity was that all factor loadings were greater than 0.6 , the $t$ values were significantly greater than 2 , and each loading was greater than double its standard error (Anderson and Gerbing 1988). CR and AVE values were calculated for each construct (Bagozzi and Yi 2012); all CR values were above 0.88 and all AVEs were above 0.55 , indicating satisfactory levels of reliability. To assess discriminant validity, the square roots of the AVEs, as per the diagonals within Table 2, were assessed against the interconstruct correlations (Fornell and Larcker 1981). All values were higher than the interconstruct correlations, thus demonstrating good evidence of discriminant validity.

To test for interaction effects between internal and external collaboration ( $\mathrm{H} 7)$, we use the latent moderated structural (LMS) method (Klein and Moosbrugger 2000) available in Mplus 8. LMS is a relatively robust method for assessing interaction effects embedded in a structural model (Little, Bovaird, and Widaman 2009). The structural model, as depicted in Figure 1, was tested in two stages because the LMS method does not provide standard fit indices (i.e., RMSEA, CFI) but rather tests against an alternative nested model that does not include the interaction effect. In the LMS method, the interaction term becomes another independent variable, which reduces the

Table 1. Item statistics and reliabilities.

\begin{tabular}{|c|c|c|c|c|c|}
\hline Construct & Mean & Deviation & Loading & $\mathrm{CR}$ & AVE \\
\hline \multicolumn{6}{|l|}{ Proactiveness } \\
\hline I am constantly on the lookout for new ways to improve my life. & 5.460 & 1.332 & 0.756 & 0.931 & 0.577 \\
\hline Wherever I have been, I have been a powerful force for constructive change. & 5.099 & 1.136 & 0.769 & & \\
\hline Nothing is more exciting than seeing my ideas turn into reality. & 5.675 & 1.257 & 0.740 & & \\
\hline If I see something I don't like, I fix it. & 5.463 & 1.213 & 0.786 & & \\
\hline No matter the odds, if I believe in something, I make it happen. & 5.087 & 1.191 & 0.767 & & \\
\hline I love being a champion for my ideas, even against others' opposition. & 5.242 & 1.308 & 0.708 & & \\
\hline I excel at identifying opportunities. & 5.323 & 1.292 & 0.784 & & \\
\hline I am always looking for better ways to do things. & 5.578 & 1.228 & 0.858 & & \\
\hline If I believe an idea, no obstacle will prevent me from making it happen. & 4.832 & 1.305 & 0.679 & & \\
\hline I can spot a good opportunity long before others can. & 4.944 & 1.209 & 0.734 & & \\
\hline \multicolumn{6}{|l|}{ Internal collaboration } \\
\hline Sharing ideas, information, and/or resources & 5.608 & 1.320 & 0.844 & 0.936 & 0.709 \\
\hline Working together as a team & 5.728 & 1.270 & 0.891 & & \\
\hline Conducting joint planning to anticipate and resolve operational problems & 5.513 & 1.418 & 0.828 & & \\
\hline Achieving goals collectively & 5.494 & 1.390 & 0.911 & & \\
\hline Developing a mutual understanding of responsibilities & 5.544 & 1.305 & 0.836 & & \\
\hline Making joint decisions about ways to improve overall cost efficiency & 5.215 & 1.482 & 0.730 & & \\
\hline \multicolumn{6}{|l|}{ External collaboration } \\
\hline Sharing ideas, information, and/or resources & 5.435 & 1.244 & 0.772 & 0.926 & 0.676 \\
\hline Working together as a team & 5.329 & 1.274 & 0.847 & & \\
\hline Conducting joint planning to anticipate and resolve operational problems & 5.453 & 1.414 & 0.853 & & \\
\hline Achieving goals collectively & 5.491 & 1.295 & 0.919 & & \\
\hline Developing a mutual understanding of responsibilities & 5.435 & 1.327 & 0.836 & & \\
\hline Making joint decisions about ways to improve overall cost efficiency & 4.590 & 1.575 & 0.686 & & \\
\hline \multicolumn{6}{|l|}{ Performance of the key account manager } \\
\hline Contributing to your company acquiring good market share & 5.494 & 1.122 & 0.833 & 0.898 & 0.640 \\
\hline Selling high-profit-margin products & 5.323 & 1.217 & 0.710 & & \\
\hline Generating a high level of euro sales & 5.497 & 1.175 & 0.895 & & \\
\hline Exceeding sales targets & 5.310 & 1.178 & 0.830 & & \\
\hline Assisting your manager to achieve his or her goals & 5.671 & 0.987 & 0.704 & & \\
\hline
\end{tabular}

Note: $\mathrm{CR}=$ composite reliability; $\mathrm{AVE}=$ average variance extracted. 
Table 2. Discriminant validity.

Means Standard deviation Proactiveness Internal collaboration External collaboration KAM performance

\begin{tabular}{llllll}
\hline Proactiveness & 5.454 & 0.956 & $0.760^{\mathrm{a}}$ & & \\
Internal collaboration & 5.380 & 1.190 & 0.710 & $0.830^{\mathrm{a}}$ & $0.826^{\mathrm{a}}$ \\
External collaboration & 5.380 & 1.125 & 0.701 & 0.652 & 0.292 \\
KAM performance & 5.260 & 0.983 & 0.372 & 0.197 & $0.800^{\mathrm{a}}$ \\
\hline
\end{tabular}

Note: ${ }^{\mathrm{a}}$ Items on the diagonal are the square root of the average variance extracted (AVE).

potential for Type I error (Muthén and Muthén 2017). If the interaction model is better than the model without the interaction effect, then the hypothesized interaction should be included (Cortina, Chen, and Dunlap 2001).

\section{Results}

The model, as per Figure 1, was first tested without the interaction effect that is excluding $\mathrm{H} 7$. The fit of the model was acceptable $\left(\chi^{2}=787.046, \mathrm{df}=387, p=.000\right.$, $\mathrm{CFI}=0.880, \mathrm{RMSEA}=0.083, \mathrm{SRMR}=0.062)($ Bagozzi and Yi 2012). The second model included the interaction hypothesis (H7). The two most important statistics for comparison are the log likelihood (LL) value and Akaike information criterion (AIC) value (Akaike 1974). The AIC, unlike other model fit indicators, does not test against a null hypothesis; rather, it tests against the AIC of a nested model. AIC is a good measure of fit as it penalizes the addition of extra parameters to over fit the model. When comparing models, the model with the lower AIC is preferred (Akaike 1974).

In LMS, the LL ratio statistic is used to determine how many times more likely the data are to occur with the model including the interaction effect(s) than with the linear model (Klein and Moosbrugger 2000). Using the LL statistics, scaling correction factors, and a number of parameters from each model (Satorra and Bentler 2010), a chi-squared test using two times the LL difference (-2LL) is calculated. In this case, the LL statistics were 5,210.096 for the base model and 5,196.364 for the full model. The Satorra and Bentler (2010) test was applied, which uses the scaling effects and an maximum likelihood parameter estimates with standard errors and a mean-adjusted chisquare test statistic that are robust to non-normality (MLM) estimator, and the $p$ value for the -2LL test was $p<.00001$, showing a significant difference between the two models (Marsh, Wen, and Hau 2004), thus providing support for the inclusion of the interaction effect. Further support is provided, in that the AIC is lower for the full model (10,592.728 versus 10,612.191). Figure 2 and Table 3 show the results of the model and the effects of the control variables.

The results show support for $\mathrm{H} 1, \mathrm{H} 2, \mathrm{H} 3, \mathrm{H} 4$, and $\mathrm{H} 7$. As the outcome of the model including the interaction hypothesis does not provide standardized results, we provide here the standardized results from the prior stage. As expected, proactiveness was positively related to internal collaboration $(\mathrm{b}=0.686, p=.000$ ), thus supporting H1. $\mathrm{H} 2$, which considered the direct effect of proactiveness on external collaboration, was supported $(\mathrm{b}=0.491, p=.000)$. There was also an indirect effect, through internal collaboration, of the impact of proactiveness on external collaboration, with the total effect amounting to 0.831 . Proactiveness was also shown to have a direct effect on performance (H3) $(\mathrm{b}=0.396, p=.004)$. Although not directly tested, the indirect effect was also measured through both forms of collaboration. The cumulative effect was 0.642. The fourth hypothesis suggested that internal collaboration had a direct

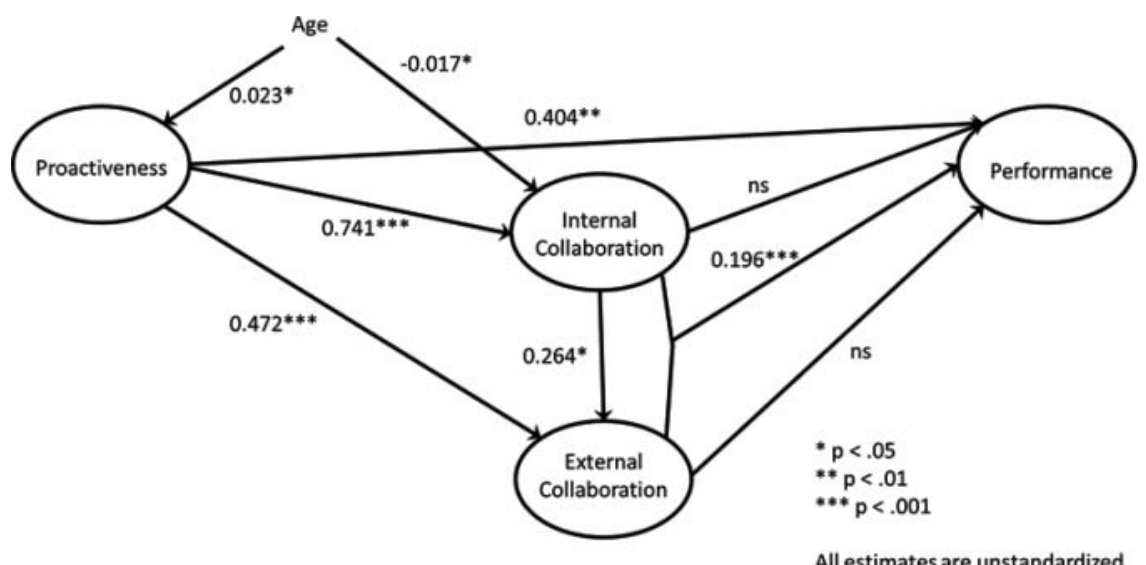

Figure 2. Structural model with interaction effect. 
Table 3. Results.

\begin{tabular}{lcccc}
\hline Hypothesis & Unstandardized loading & Standard error & T value & Significance \\
\hline H1 & 0.741 & 0.095 & 7.783 & 0.000 \\
H2 & 0.472 & 0.123 & 2.846 & 0.000 \\
H3 & 0.404 & 0.146 & 2.745 & 0.006 \\
H4 & 0.264 & 0.107 & -1.243 & 0.014 \\
H5 & -0.191 & 0.154 & -0.710 & 0.214 \\
H6 & -0.122 & 0.171 & 4.771 & 0.478 \\
H7 & 0.196 & 0.041 & External collaboration & KAM performance \\
Controls & Internal collaboration & ns & $-0.004(p=.053)$ \\
\hline No. of acc. & Proactiveness & ns & ns & ns \\
Age & $0.023(p=.029)$ & $0.017(p=.044)$ & ns \\
Gender & ns & ns & & \\
\hline
\end{tabular}

positive effect on external collaboration (H4), and support $(\mathrm{b}=0.296, p=.002)$ was found for these effects. However, neither internal collaboration (H5) nor external collaboration (H6) had a direct effect on performance. Interestingly, this lack of direct effects was evident in both the model with and the model without the interaction hypothesis. Finally, H7 posited that the interaction between internal and external collaboration would positively affect performance. Strong support was found for this relationship with the unstandardized path estimate being $0.196(p=.000)$. In terms of the control variables, the number of accounts had a marginal negative effect, at just over the $5 \%$ level, on performance. Age showed two significant effects, demonstrating that older individuals had higher levels of proactiveness, providing support for Mallin, Ragland, and Finkle (2014), who found the same effect in their sample. Older individuals also had higher levels of internal collaboration, which may be a proxy for their experience in the role and their knowledge of how organizations work. Gender had no significant effects on any of the constructs in the model.

\section{Discussion and implications \\ General discussion}

In this research, we demonstrate that the relationship between collaboration and performance may be more nuanced than previously understood. Le Meunier-FitzHugh and Piercy (2007) and Kotler, Rackham, and Krishnaswamy (2006) have argued that internal collaboration with other parts of an organization leads to greater levels of success. Homburg, Workman, and Jensen (2002) and Ulaga and Eggert (2006) provided support for the contention that collaboration with customers leads to greater success. Our research, however, did not find specific support for these individual relationships established in the literature. Interestingly, we found that it is the joint effect of internal and external collaboration that has a significant effect on performance. Adding to the literature on collaboration, we also posited relationships between proactiveness - a previously not well-studied personality variable in key account management - and sales, context, and our key concepts of collaboration and performance. We found strong support for the role of proactiveness in generating higher levels of collaboration and performance.

Providing support for $\mathrm{H} 1$, we found that proactiveness had a strong positive effect on the level of internal collaboration. Spitzmuller et al. (2015), in a large meta-analysis of studies on proactiveness and the Big Five personality traits, found that highly proactive individuals are more conscientious and, perhaps unsurprisingly, more extraverted than others. Similarly, traits associated with being proactive lead to stronger levels of collaboration with external customers, thus supporting H2. Validating the contention by Mallin, Ragland, and Finkle (2014) that being proactive leads to higher levels of performance, we found a significant positive relationship between proactiveness and performance (H3). Seibert, Crant, and Kraimer (1999) suggested that more proactive individuals take greater control of the situations in which they work. Even though there have been two largescale meta-analytic studies on proactiveness (Spitzmuller et al. 2015; Thomas, Whitman, and Viswesvaran 2010), we add to the literature in this area by demonstrating the importance of proactiveness in driving internal and external collaborative activities.

We add to the key account management literature by considering the role of collaboration in driving performance. We posited relationships between internal and external collaboration and between both internal and external collaboration and performance, as well as the joint effect of both internal and external forms of collaboration and performance. Our results provide a more finegrained view of the role of collaboration in performance enhancement in a key account management context. Empirical evidence for a relationship between both forms of collaboration exists (Stank, Keller, and Daugherty 2001) and we found support for the contention that a 
higher level of internal collaboration drives higher levels of external collaboration (H4). This result provides support for the key tenets of key account management, which emphasize the importance of collaboration (Pardo et al. 2006), both externally (Schultz and Evans 2002) and internally (Henneberg et al. 2009). The importance of internal collaboration in attaining higher levels of external collaboration provides a more nuanced understanding of how relationships inside an organization affect those with external stakeholders.

Our final set of hypotheses (H5, H6, and H7) examined the effects of collaboration on the performance of the key account manager. Despite strong evidence in the literature (Le Meunier-FitzHugh and Piercy 2007; Spekman and Carraway 2006; Stank, Keller, and Daugherty 2001) that internal collaboration has an independent effect on performance, we did not find support for this hypothesis. Likewise, we did not find direct support for the notion that a higher level of external collaboration, in itself, leads to a higher level of performance, a concept that is well rooted in the literature (Jap 1999; Ulaga and Eggert 2006; Workman, Homburg, and Jensen 2003). Given the crosssectional approach employed, and the use of self-report measures, the lack of support for an independent relationship between both forms of collaboration and performance is interesting. Notably, when we tested the model without the interaction effect, as reported in the first stage of our results section, the same outcomes held for both H5 and H6. The key account management context seems to be where the management of a portfolio of relationships (Plouffe et al. 2016) is required to be successful. This is borne out strongly in our study. It seems that internal and external collaboration, albeit present in key account relationships, are insufficient on their own to generate higher levels of performance.

In the key account management context, this result is somewhat expected. Key account managers must collaborate both internally and externally to generate value for the organization. They will not know which internal resources to harness unless they collaborate with their external customer. Key account managers will not be able to provide a compelling value proposition to the external customer without first understanding what value their internal organization can bring to the table. While this article finds support for their role as internal orchestrators of resources (Corcoran et al. 1995), we suggest that this orchestration capability extends beyond organization boundaries to encompass their key accounts. Both internal and external collaboration are required to create value and to enhance performance.

\section{Theoretical implications}

This study extends SET to allow us to understand how collaborative relationships are built with strategically important customers at the level of the individual key account manager (Guenzi, Georges, and Pardo 2009; Sengupta et al. 2000). First, it demonstrates the importance of proactiveness and its influence on the critical variables of collaboration and performance. Second, this model is the first to highlight the interaction effect of internal and external collaboration on key account performance. While previous studies have focused on internal or external collaboration, these studies do not fully capture the totality of the role of the key account manager, which encompasses internal collaboration while also collaborating externally with the customer. This result has implications for how SET is useful in the key account relationship context.

Key account managers are a classic case of interdependency within the SET lens (Cropanzano and Mitchell 2005). They are dependent not only on their own organization to fulfil their needs, but also on their customer to be able to win business for their organization. As a result, the social exchanges that key account managers have with one group that they deal with, such as customers, generate spillover effects into the other relationships that they have within their organizations. As these are long-term relationships within the SET framework, our results can be explained by the concept of reciprocity as a norm, rather than the classic idea of reciprocity as a set of interdependent exchanges (Lambe et al. 2001). This implies that the key account relationship is conceptualized not as a series of exchanges, but as a relational norm (Cropanzano and Mitchell 2005). As there are costs associated with being in relationships, SET suggests that a relationship will continue as long as satisfactory economic outcomes (e.g., financial rewards) are gained. Our empirical results, showing a strong positive relationship between collaboration and performance, provide support for the economic outcomes of relationships using a SET lens (Lambe et al. 2001).

\section{Managerial implications}

With increases in psychometric testing in recruitment and selection processes, the inclusion of proactiveness may be useful for recruitment managers who wish to hire highquality key account managers. Psychometric testing to exclude potential candidates needs to be fair and equitable. Spitzmuller et al. (2015) found that there are no subgroup differences in proactiveness by gender or race, which makes it an ideal candidate for screening. In the absence of such testing, competency-based interviews could be useful to ask candidates to describe situations where they have been proactive and have made changes in order to do things better. A sample question for a manager to ask would be "Describe a situation where you took the initiative and led change to improve business processes." Proactive individuals are likely to try to change 
their job situation to improve the likelihood of higher performance (Crant 1995). This shaping of their work environment can be problematic for managers, in that proactive individuals may challenge decisions they do not perceive as being in their interest. For proactive employees, the level of proactive behavior demonstrated by leaders can increase their productivity (Yang et al. 2017) and enhance other work outcomes (Zhang, Wang, and Shi 2012). Less-proactive managers can see highly proactive individuals as distractions or even as threats (Grant, Gino, and Hofmann 2011).

Should the work situation be negative for proactive employees, the literature suggests that they are more likely to leave than to stay (Crant 2000). This is borne out by research that suggests that proactive individuals are better at job-search activities (Fuller and Marler 2009) and tend to be more open to new experiences (Spitzmuller et al. 2015). However, more recent literature (Joo, Hahn, and Petersen 2015) found no significant effect when controlling for perceived organizational support, developmental feedback, and job complexity. It seems then that potentially high-performing, proactive individuals may remain in less than ideal situations if they feel supported by the organization, they receive regular high-quality feedback on their performance, and their job is perceived to be complex.

We also show that for key account managers to enhance their performance, they need to balance their portfolio of relationships (Plouffe et al. 2016) both within and outside their own organization. In essence, key account managers cannot succeed unless they are working with both internal and external stakeholders. The management of internal relationships is key to organizations (Ritter and Gemünden 2003). Given the complexity within which organizations operate, there is also a growing need for integration between functions that are responsible for relationships with customers within an organization (Kahn and Mentzer 1998; Sheth, Sisodia, and Sharma 2000). Pagell (2004) suggests that this can be achieved through appropriate reward structures, balancing formal and informal communication, and managing the structure and culture of the organization. Drawing from the alliance literature (Schreiner, Kale, and Corsten 2009), we suggest that social bonding activities would be a useful technique to build relationships among internal departments and the key account manager. For example, in our interviews, we found that key account managers make presentations internally to educate the internal departments about the customer, their future plans, and the implications of those for the organization. These are built around a team-building agenda to ensure that the key account manager can more easily build relationships with key individuals within the organization. Despite the importance of internal collaboration, this research shows that external collaboration is also essential to drive higher performance. This is often a more challenging prospect for organizations. Taking the time to build relationships, not only with the counterpart of the key account manager but also with key individuals in their organization, is essential to enhance these mutually beneficial relationships. Organizations must also be cognizant of the relationships built up in key account structures when redeploying staff to cover absences or indeed when a key account manager leaves. The replacement decision is particularly important. From our interviews, we found that organizations find the skill set of a successful key account manager difficult to find in the external labor market, particularly with respect to managing relationships both inside and outside organizational boundaries. Balancing a portfolio of relationships is not a simple process, but organizations need to support both forms of collaboration to achieve their goals.

\section{Limitations and future research}

While this study contributes to both literature and practice, there are some limitations that open future research avenues. This study was conducted in Ireland, which is a small, open economy enjoying the benefits of European Union membership. Future studies could be conducted across different countries and cultural contexts, thus enhancing the generalizability of this study. The key account manager respondents were drawn from a wide range of industries, thus showing that the relationships hold in a variety of contexts. Future studies focusing on specific industries may find contextual effects that would moderate the relationships found here. For example, in an industry with significant degrees of end-customer customization, it is possible that proactiveness and internal collaboration would be more important, given the difficulty of managing mass-customization facilities.

Pitt, Ewing, and Berthon (2002), in a key study on proactiveness in a sales setting, found differing levels of proactiveness in their sample. While the current study generally found high levels of proactiveness, a study with a wider range of salespeople might shed light on the conditions under which being proactive may bring the most benefits for an organization. Proactiveness has also been associated with personal initiative (Fay and Frese 2001), and it would be of interest to organizations to understand how the two concepts interact in collaborative activities within, and outside, the organization. Given the collaborative nature of the key account manager, a higher degree of proactiveness would seem logical for this boundary-spanning role. This article concentrates on the key account manager as the focal individual. However, the purchasing counterparts may perceive the level of proactiveness of the key account manager as being positive when the key account manager is working on behalf of the purchaser and potentially negative when the key account manager 
is clearly operating on behalf of his or her own organization. A dyadic study of how the level of perceived proactiveness of the key account manager affects the customer organization would also be of interest.

This study specifically deals with key account managers, for whom collaboration with internal colleagues and external customers is an important way of working. It would be interesting to understand whether the same effect occurs when one form of collaboration is not as important for salesperson success. It may be possible that there are relationship-stage effects (Yen and Barnes 2011), particularly in relation to how internal and external collaboration interact to enhance performance. It may be that one form of collaboration is more important at a particular relationship stage. One way to test this would be to conduct a longitudinal study (Bolander, Dugan, and Jones 2017) with a set of key accounts as partners initiate and subsequently develop their portfolio of relationships (Plouffe et al. 2016). Such an approach, through repeated measures of the collaboration constructs, may be useful in understanding how different forms of collaboration work together as relationships develop over time.

\section{Declaration of interest}

No potential conflict of interest was reported by the authors.

\section{References}

Akaike, Hirotugu. 1974. "A New Look at the Statistical Model Identification." IEEE Transactions on Automatic Control 19:716-723. doi:10.1109/TAC.1974.1100705.

Anderson, James C., and David W. Gerbing. 1988. "Structural Equation Modeling in Practice: A Review and Recommended Two-Step Approach." Psychological Bulletin 103 (3):411-423. doi:10.1037/0033-2909.103.3.411.

Ang, Siah Hwee. 2008. "Competitive Intensity and Collaboration: Impact on Firm Growth Across Technological Environments." Strategic Management Journal 29 (10):1057-1075. doi:10.1002/smj.695.

Armstrong, J. Scott, and Terry S. Overton. 1977. "Estimating Non-Response Bias in Mail Surveys." Journal of Marketing Research 14 (3):396-402. doi:10.2307/3150783.

Bagozzi, Richard P., and Youjae Yi. 2012. "Specification, Evaluation and Interpretation of Structural Equation Models." Journal of the Academy of Marketing Science 40:8-34. doi:10.1007/s11747-011-0278-x.

Barrick, Murray R., and Michael K. Mount. 1991. "The Big Five Personality Dimensions and Job Performance: A Meta-Analysis." Personnel Psychology 44 (1):1-26. doi:10.1111/j.1744-6570.1991.tb00688.x.

Bateman, Thomas S., and J. Michael Crant. 1993. "The Proactive Component of Organizational Behaviour: A Measure and Correlates." Journal of Organizational Behavior 14:103-118. doi:10.1002/job.4030140202.

Blau, Peter Michael. 1964. Exchange and Power in Social Life. London, UK: Transaction Publishers.

Bolander, Willy, Cinthia B. Satornino, Douglas E. Hughes, and Gerald R. Ferris. 2015. "Social Networks Within Sales
Organizations: Their Development and Importance for Salesperson Performance." Journal of Marketing 79 (6):116. doi:10.1509/jm.14.0444.

Bolander, Willy, Riley Dugan, and Eli Jones. 2017. "Time, Change, and Longitudinally Emergent Conditions: Understanding and Applying Longitudinal Growth Modeling in Sales Research." Journal of Personal Selling \& Sales Management 37 (2):153-169. doi:10.1080/08853134. 2017.1314187.

Boles, James, Wesley Johnston, and Alston Gardner. 1999. "The Selection and Organisation of National Accounts: A North American Perspective." Journal of Business and Industrial Marketing 14 (4):264-275. doi:10.1108/08858629910279871.

Bucklin, Louis P., and Sanjit Sengupta. 1993. "Organizing Successful Co-Marketing Alliances." Journal of Marketing 57 (2):32-46. doi:10.2307/1252025.

Cai, Shaohan, Minjoon Jun, and Zhilin Yang. 2017. "The Effects of Boundary Spanners' Personal Relationships on Interfirm Collaboration and Conflict: A Study of the Role of Guanxi in China." Journal of Supply Chain Management 53 (3):1940. doi:10.1111/jscm.12132.

Corcoran, Kevin J., Laura K. Peterson, Daniel B. Baitch, and Mark F. Barrett. 1995. High Performance Sales Organizations. Chicago, IL: Richard D. Irwin.

Cortina, Jose M., Gilad Chen, and William P. Dunlap. 2001. "Testing Interaction Effects in LISREL: Examination and Illustration of Available Procedures." Organizational Research Methods 4:324-360. doi:10.1177/1094428 10144002.

Crant, J. Michael. 1995. "The Proactive Personality Scale and Objective Job Performance Among Real Estate Agents." Journal of Applied Psychology 80:532-537. doi:10.1037/ 0021-9010.80.4.532.

Crant, J. Michael. 2000. "Proactive Behavior in Organizations." Journal of Management 26:435-462. doi:10.1177/014920 630002600304.

Cropanzano, Russell, and Marie S. Mitchell. 2005. "Social Exchange Theory: An Interdisciplinary Review." Journal of Management 31 (6):874-900. doi:10.1177/0149206305279602.

Davies, Ian A., and Lynette Ryals. 2013. "Attitudes and Behaviours of Key Account Managers: Are They Really Any Different to Senior Sales Professionals?" Industrial Marketing Management 42:919-931. doi:10.1016/j.indmarman.2013.02.019.

De Luca, Luigi, and Kwaku Atuahene-Gima. 2007. "Market Knowledge Dimensions and Cross-Functional Collaboration: Examining the Different Routes to Product Innovation Performance." Journal of Marketing 71:95-112. doi:10. 1509/jmkg.71.1.95.

Den Hartog, Deanne N., and Frank D. Belschak. 2007. "Personal Initiative, Commitment and Affect at Work." Journal of Occupational and Organizational Psychology 80:601-622. doi:10.1348/096317906X171442.

Denscombe, Martyn. 2003. The Good Research Guide: For Small-Scale Social Research Projects. Berkshire, England: Open University Press.

Dwyer, F. Robert., Paul H. Schurr, and Sejo Oh. 1987. "Developing Buyer-Seller Relationships." Journal of Marketing 51 (April):11-27. doi:10.2307/1251126.

Ellinger, Alexander E. 2000. "Improving Marketing/Logistics Cross-Functional Collaboration in the Supply Chain." Industrial Marketing Management 29 (1):85-96. doi:10.1016/ S0019-8501(99)00114-5.

Emerson, Richard. M. 1976. "Social Exchange Theory." Annual Review of Sociology 2 (1):335-362. doi:10.1146/annurev. so.02.080176.002003. 
Erdogan, Berrin, and Talya N. Bauer. 2005. "Enhancing Career Benefits of Employee Proactive Personality: The Role of Fit with Jobs and Organizations." Personnel Psychology 58 (4):859-891. doi:10.1111/j.1744-6570.2005.00772.x.

Evans, Kenneth, Richard McFarland, Bart Dietz, and Fernando Jaramillo. 2012. "Advancing Sales Performance Research: A Focus on Five Under Researched Topic Areas." Journal of Personal Selling \& Sales Management 32 (1):89-105. doi:10.2753/PSS0885-3134320108.

Fay, Doris, and Michael Frese. 2001. "The Concept of Personal Initiative: An Overview of Validity Studies." Human Performance 14 (1):97-124. doi:10.1207/S15327043HUP1401_06.

Flaherty, Karen E., and James M. Pappas. 2009. "Expanding the Sales Professional's Role: A Strategic Re-Orientation?" Industrial Marketing Management 38 (7):806-813. doi:10.1016/j.indmarman.2008.04.007.

Flynn, Francis J. 2003. "How Much Should I Give and How Often? The Effects of Generosity and Frequency of Favor Exchange on Social Status and Productivity." Academy of Management Journal 46 (5):539-553. doi:10.2307/30040648.

Fornell, Claes, and David F. Larcker. 1981. "Evaluating Structural Equation Models with Unobservable Variables and Measurement Error." Journal of Marketing Research 18:39_ 50. doi:10.2307/3151312.

Froehle, Craig, and Aleda V. Roth. 2004 "New Measurement Scales for Evaluating Perceptions of the Technology-Mediated Customer Service Experience." Journal of Operations Management 22:1-21. doi:10.1016/j.jom.2003.12.004.

Fuller, Bryan, and Laura E. Marler. 2009. "Change Driven by Nature: A Meta-Analytic Review of the Proactive Personality Literature." Journal of Vocational Behavior 75 (3):329_ 345. doi:10.1016/j.jvb.2009.05.008.

Georges, Laurent, and Andreas Eggert. 2003. "Key Account Manager's Role Within the Value Creation Process of Collaborative Relationships." Journal of Business to Business Marketing 10 (4):1-22. doi:10.1300/J033v10n04_01.

Goold, Michael, and Andrew Campbell. 1998. "Desperately Seeking Synergy.” Harvard Business Review 76 (5):130-143.

Grant, Adam M., and Susan J. Ashford. 2008. "The Dynamics of Proactivity at Work." Research in Organizational Behaviour 28:3-34. doi:10.1016/j.riob.2008.04.002.

Grant, Adam M., Francesca Gino, and David A. Hofmann. 2011. "Reversing the Extraverted Leadership Advantage: The Role of Employee Proactivity." Academy of Management Journal 54 (3):528-550. doi:10.5465/AMJ.2011.61968043.

Griffin, Mark A., Andrew Neal, and Sharon K. Parker. 2007. “A New Model of Work Role Performance: Positive Behavior in Uncertain and Interdependent Contexts." Academy of Management Journal 50 (2):327-347. doi:10.5465/ AMJ.2007.24634438.

Guenzi, Paulo, Catherine Pardo, and Laurent Georges. 2007. "Relational Selling Strategy and Key Account Managers' Relational Behaviours: An Exploratory Study." Industrial Marketing Management 36:122-133. doi:10.1016/j. indmarman.2005.03.014.

Guenzi, Paulo, Laurent Georges, and Catherine Pardo. 2009. "The Impact of Strategic Account Managers' Behaviours on Relational Outcomes: An Empirical Study." Industrial Marketing Management 38:300-311. doi:10.1016/j.indmarman. 2007.09.011.

Henneberg, Stephan, Catherine Pardo, Stephano Mouzas, and Peter Naudé. 2009. "Value Dimensions and Relationship Postures in Dyadic Key Relationship Programmes." Journal of Marketing Management 25 (5-6):535-550. doi:10.1362/ 026725709 X461849.
Homburg, Christian, John P. Workman Jr., and Ove Jensen. 2000. "Fundamental Changes in Marketing Organization: The Movement Toward a Customer-Focused Organizational Structure." Journal of the Academy of Marketing Science 28 (4):459-479. doi:10.1177/0092070300284001.

Homburg, Christian, John P. Workman Jr., and Ove Jensen. 2002. "A Configurational Perspective on Key Account Management." Journal of Marketing 66 (April):38-60. doi:10.1509/jmkg.66.2.38.18471.

Houston, Franklin S., Jule B. Gassenheimer, and James M. Maskulka. 1992. Marketing Exchange Transactions and Relationships. Westport, CT: Quorum Books.

Hughes, Douglas E., Joël Le Bon, and Avinash Malshe. 2012. "The Marketing-Sales Interface at the Interface: Creating Market-Based Capabilities Through Organizational Synergy." Journal of Personal Selling \& Sales Management 32 (1):57-72. doi:10.2753/PSS0885-3134320106.

Hulland, John, Hans Baumgartner, and Keith Marion Smith. 2017. "Marketing Survey Research Best Practices: Evidence and Recommendations from a Review of JAMS Articles." Journal of the Academy of Marketing Science 46 (1):92108. doi:10.1007/s11747-017-0532-y.

Hunt, Shelby D. 1997. "Competing Through Relationships: Grounding Relationship Marketing in Resource Advantage Theory." Journal of Marketing Management 13 (5):431445. doi:10.1080/0267257X.1997.9964484.

Hutt, Michael D. 1995. "Cross-Functional Working Relationships in Marketing." Journal of the Academy of Marketing Science 23 (4):351-357. doi:10.1007/BF02893875.

Jap, Sandy. 1999. "Pie Expansion Efforts: Collaboration Processes in Buyer-Seller Relationships." Journal of Marketing Research 36 (4):461-475. doi:10.2307/3152000.

Joo, Baek-Kyoo and Taejo Lim. 2009. "The Effects of Organizational Learning Culture, Perceived Job Complexity, and Proactive Personality on Organizational Commitment and Intrinsic Motivation." Journal of Leadership \& Organizational Studies 16 (1):48-60. doi:10.1177/1548051809334195.

Joo, Baek-Kyoo, Huh-Jung Hahn, and Shari L. Peterson. 2015 "Turnover Intention: The Effects of Core Self-Evaluations, Proactive Personality, Perceived Organizational Support, Developmental Feedback, and Job Complexity." Human Resource Development International 18 (2):116-130. doi:10.1080/13678868.2015.1026549.

Kahn, Kenneth B. 1996. "Interdepartmental Integration: A Definition with Implications for Product Development Performance." Journal of Product Innovation Management 13 (2):137-151. doi:10.1016/0737-6782(95)00110-7.

Kahn, Kenneth B., and John T. Mentzer. 1998. "Marketing's Integration with Other Departments." Journal of Business Research 42 (1):53-62. doi:10.1016/S0148-2963(97)00068-4.

Kashyap, Vishal, and Eugene Sivadas. 2012. "An Exploratory Examination of Shared Values in Channel Relationships." Journal of Business Research 65 (5):586-593. doi:10.1016/ j.jbusres.2011.02.008.

Kim, Daekwan, and Ruby Lee. 2010. "Systems Collaboration and Strategic Collaboration: Their Impacts on Supply Chain Responsiveness and Market Performance." Decision Sciences 41 (4):955-981. doi:10.1111/j.1540-5915.2010.00289.x.

Klein, Andreas, and Helfried Moosbrugger. 2000. "Maximum Likelihood Estimation of Latent Interaction Effects with the LMS Method." Psychometrika 65:457-474. doi:10.1007/ BF02296338.

Kotler, Philip, Neil Rackham, and Suj Krishnaswamy. 2006. "Ending the War Between Sales and Marketing." Harvard Business Review 84 (7/8):68-78. 
Lambe Jay C., C. Michael Wittmann, and Robert E. Spekman 2001. "Social Exchange Theory and Research on Businessto-Business Relational Exchange." Journal of Business to Business Marketing 8:1-36. doi:10.1300/J033v08n03_01.

Le Meunier-FitzHugh, Kenneth, and Nikala Lane. 2009. "Collaboration Between Sales and Marketing, Market Orientation and Business Performance in Business-to-Business Organisations." Journal of Strategic Marketing 17 (3-4):291-306. doi:10.1080/09652540903064860.

Le Meunier-FitzHugh, Kenneth, and Nigel F. Piercy. 2007. "Does Collaboration Between Sales and Marketing Affect Business Performance?" Journal of Personal Selling \& Sales Management 27 (3):207-220. doi:10.2753/PSS08853134270301.

Le Meunier-FitzHugh, Kenneth, and Nigel F. Piercy. 2009. "Drivers of Sales and Marketing Collaboration in Businessto-Business Selling Organisations." Journal of Marketing Management 25 (5-6):611-633. doi:10.1362/026725 709X461885.

Lindell, Michael K., and David J. Whitney. 2001. "Accounting for Common Method Variance in Cross-Sectional Research Designs." Journal of Applied Psychology 86 (1):114-121. doi:10.1037/0021-9010.86.1.114.

Little, Todd D., James A. Bovaird, and Keith F. Widaman. 2009. "On the Merits of Orthogonalizing Powered and Product Terms: Implications for Modeling Interactions Among Latent Variables." Structural Equation Modeling 13 (4):497-519. doi:10.1207/s15328007sem1304_1.

Lussier, Bruno, and Zachary R. Hall. 2017. "Cooperation in B2B Relationships: Factors that Influence Customers' Perceptions of Salesperson Cooperation." Industrial Marketing Management Forthcoming. doi:10.1016/j.indmarman.2017.09.019

Mallin, Michael L., and Charles B. Ragland, Todd A. Finkle. 2014. "The Proactive Behavior of Younger Salespeople: Antecedents and Outcomes." Journal of Marketing Channels 21:268-278. doi:10.1080/1046669X.2014.945359.

Marsh, Herbert W., Zhonglin Wen, and Kit-Tai Hau. 2004. "Structural Equation Models of Latent Interactions: Evaluation of Alternative Estimation Strategies and Indicator Construction." Psychological Methods 9:275-300. doi:10.1037/ 1082-989X.9.3.275.

Mavondo, Felix T., and Elaine M. Rodrigo. 2001. "The Effect of Relationship Dimensions on Interpersonal and Interorganizational Commitment in Organizations Conducting Business Between Australia and China." Journal of Business Research 52:111-121. doi:10.1016/S0148-2963(99)00064-8.

McColl, Rod, and Yann Truong. 2013. "The Effects of Facial Attractiveness and Gender on Customer Evaluations During a Web-Video Sales Encounter." Journal of Personal Selling \& Sales Management 33 (1):117-128. doi:10.2753/ PSS0885-3134330110.

Mentzer, John T., William Dewitt, James S. Keebler, Soonhong Min, Nancy Nix, Carlo D. Smith, and Zach G. Zacharia. 2001. "Defining Supply Chain Management." Journal of Business Logistics 22 (2):1-25. doi:10.1002/j.21581592.2001.tb00001.x.

Min, Soonhong, Anthony S. Roath, Patricia J. Daugherty, Stefan E. Genchev, Haozhe Chen, Aaron D. Arndt, and R. Glenn Richey. 2005. "Supply Chain Collaboration: What's Happening?" The International Journal of Logistics Management 16 (2):237-256. doi:10.1108/09574090510634539.

Molm, Linda D. 1994. "Dependence and Risk: Transforming the Structure of Social Exchange." Social Psychology Quarterly 57:163-176. doi:10.2307/2786874.
Morgan, Robert M., and Shelby D. Hunt. 1994. "The Commitment-Trust Theory of Relationship Marketing." Journal of Marketing 58:20-38. doi:10.2307/1252308.

Muthén, Linda K., and Bengt O. Muthén. 2017. Mplus User's Guide. 8th ed. Los Angeles, CA: Muthén \& Muthén.

Pardo, Catherine, Robert Salle, and Robert Spencer. 1995. "The Key Accountization of the Firm: A Case Study." Industrial Marketing Management 22:123-134. doi:10.1016/00198501(94)00039-Y.

Pagell, Mark. 2004. "Understanding the Factors that Enable and Inhibit the Integration of Operations, Purchasing and Logistics." Journal of Operations Management 22 (5):459-487. doi:10.1016/j.jom.2004.05.008.

Pardo, Catherine, Stefan Henneberg, Stefanos Mouzas, and Peter Naude. 2006. "Unpicking the Meaning of Value in Key Account Management." European Journal of Marketing 49 (11/12):1360-1374. doi:10.1108/03090560610702858.

Piercy, Nigel F. 2009. "Strategic Relationships Between Boundary-Spanning Functions: Aligning Customer Relationship Management with Supplier Relationship Management." Industrial Marketing Management 38:857-864. doi:10.1016/j.indmarman.2009.03.015.

Piercy, Nigel F. 2010. "Evolution of Strategic Sales Organisations in Business-to-Business Marketing." Journal of Business and Industrial Marketing 25 (5):349-359. doi:10.1108/ 08858621011058115.

Pinar, Musa and J. Russell Hardin. 2006. "The Effect of Gender on Recruiting for Sales Positions." Services Marketing Quarterly 27 (2):15-32. doi:10.1300/J396v27n02_02.

Pitt, Leyland F., Michael T. Ewing, and Pierre R. Berthon. 2002. "Proactive Behavior and Industrial Salesforce Performance." Industrial Marketing Management 31 (8):639-644. doi:10.1016/S0019-8501(01)00171-7.

Plouffe, Christopher R. and Donald W. Barclay. 2007. "Salesperson Navigation: The Intraorganizational Dimension of the Sales Role." Industrial Marketing Management 36 (4):528-539. doi:10.1016/j.indmarman.2006.02.002.

Plouffe, Christopher R., Willy Bolander, Joseph A. Cote, and Bryan Hochstein. 2016. "Does the Customer Matter Most? Exploring Strategic Frontline Employees' Influence of Customers, the Internal Business Team, and External Business Partners." Journal of Marketing 80 (1):106-123. doi:10.1509/jm.14.0192.

Podsakoff, Philip M., Scott B. MacKenzie, and Nathan P. Podsakoff. 2012. "Sources of Method Bias in Social Science Research and Recommendations on How to Control it." Annual Review of Rsychology 63:539-569. doi:10.1146/ annurev-psych-120710-100452.

Podsakoff, Philip M., Scott B. MacKenzie, Jeong-Yeon Lee, and Nathan P. Podsakoff. 2003. "Common Method Biases in Behavioral Research: A Critical Review of the Literature and Recommended Remedies." Journal of Applied Psychology 88 (5):879-903. doi:10.1037/0021-9010.88.5.879.

Ramaswami, Sridhar N., Srini S. Srinivasan, and Stephen A. Gorton. 1997. "Information Asymmetry Between Salesperson and Supervisor: Postulates from Agency and Social Exchange Theories." Journal of Personal Selling \& Sales Management 17 (3):29-50.

Ritter, Thomas, and Hans Georg Gemünden. 2003. "Interorganizational Relationships and Networks." Journal of Business Research 56:691-697. doi:10.1016/S0148-2963 (01)00254-5.

Ritter, Thomas, Ian F. Wilkinson, and Wesley J. Johnston. 2004. "Managing in Complex Business Networks." Industrial 
Marketing Management 33:175-183. doi:10.1016/j. indmarman.2003.10.016.

Ryals, Lynette, and Beth Rogers. 2007. "Key Account Planning: Benefits, Barriers and Best Practice." Journal of Strategic Marketing 15:209-222. doi:10.1080/09652540701320894.

Ryals, Lynette, and Simon Knox. 2001. "Cross-Functional Issues in the Implementation of Relationship Marketing Through Customer Relationship Management." European Management Journal 19 (5):534-542. doi:10.1016/S0263-2373(01)00067-6.

Sanders, Nada R. 2007. "An Empirical Study of the Impact of EBusiness Technologies on Organizational Collaboration and Performance." Journal of Operations Management 25 (6):1332-1347. doi:10.1016/j.jom.2007.01.008.

Satorra, Albert and Peter M. Bentler. 2010. "Ensuring Positiveness of the Scaled Difference Chi-square Test Statistic." Psychometrika 75:243-248. doi:10.1007/s11336-009-9135-y.

Schreiner, Melanie, Prashant Kale, and Daniel Corsten. 2009. "What Really is Alliance Management Capability and How Does it Impact Alliance Outcomes and Success?" Strategic Management Journal 30 (13):1395-1419. doi:10.1002/smj.790.

Schultz, Roberta J., and Kenneth R. Evans. 2002. "Strategic Collaborative Communication by Key Account Representatives." Journal of Personal Selling \& Sales Management 32 (1):23-31.

Seibert, Scott E., J. Michael Crant, and Maria L. Kraimer. 1999. "Proactive Personality and Career Success." Journal of Applied Psychology 84 (3):416-427. doi:10.1037/00219010.84.3.416.

Sengupta, Sanjit, Robert E. Krapfel, and Michael A. Pusateri. 2000. "An Empirical Investigation of Key Account Salesperson Effectiveness." Journal of Personal Selling \& Sales Management 20 (4):253-261.

Sheth, Jagdish N. 1996. "Organizational Buying Behavior: Past Performance and Future Expectations." Journal of Business \& Industrial Marketing 11 (3/4):7-24. doi:10.1108/ 08858629610125441.

Sheth, Jagdish N., Rajendra S. Sisodia, and Arun Sharma. 2000. "The Antecedents and Consequences of Customer-Centric Marketing." Journal of the Academy of Marketing Science 28 (1):55-66. doi:10.1177/0092070300281006.

Singh, Kulwant, and Will Mitchell. 2005. "Growth Dynamics: The Bidirectional Relationship Between Interfirm Collaboration and Business Sales in Entrant and Incumbent Alliances." Strategic Management Journal 26 (6):497-521. doi:10.1002/smj.462.

Smirnova, Maria, Stephan C. Henneberg, Bahar Ashnai, Peter Naudé, and Stefanos Mouzas. 2011. "Understanding the Role of Marketing-Purchasing Collaboration in Industrial Markets: The Case of Russia." Industrial Marketing Management 40 (1):54 64. doi:10.1016/j.indmarman.2010.09.010.

Speakman, James, and Lynette Ryals. 2012. "Key Account Management: The Inside Selling Job." Journal of Business and Industrial Marketing 27 (5):360-369. doi:10.1108/ 08858621211236034.

Spekman, Robert E., and Robert Carraway. 2006. "Making the Transition to Collaborative Buyer-Seller Relationships: An Emerging Framework." Industrial Marketing Management 35 (1):10-19. doi:10.1016/j.indmarman.2005.07.002.

Spekman, Robert E., Deborah J. Salmond, and C. Jay Lambe. 1997. "Consensus and Collaboration: Norm-Regulated
Behaviour in Industrial Marketing Relationships.” European Journal of Marketing 31 (11/12):832-856. doi:10.1108/ 03090569710190569.

Spitzmuller, Matthias, Hock-Peng Sin, Michael Howe, and Shereen Fatimah. 2015. "Investigating the Uniqueness and Usefulness of Proactive Personality in Organizational Research: A Meta-Analytic Review." Human Performance 28 (4):351-379. doi:10.1080/08959285.2015.1021041.

Stank, Theodore P., Scott B. Keller, and Patricia J. Daugherty. 2001. "Supply Chain Collaboration and Logistical Service Performance." Journal of Business Logistics 22 (1):29-48. doi:10.1002/j.2158-1592.2001.tb00158.x.

Thomas, Jeffrey P., Daniel S. Whitman, and Chockalingam Viswesvaran. 2010. "Employee Proactivity in Organizations: A Comparative Meta-Analysis of Emergent Proactive Constructs." Journal of Occupational and Organizational Psychology 83 (2):275-300. doi:10.1348/096317910X502359.

Thompson, Jeffrey A. 2005. "Proactive Personality and Job Performance: A Social Capital Perspective." Journal of Applied Psychology 90:1011-1017. doi:10.1037/0021-9010.90.5.1011.

Tzempelikos, Nektarios, and Spiros Gounaris. 2013. "Approaching Key Account Management from a LongTerm Perspective." Journal of Strategic Marketing 21 (2):179-198. doi:10.1080/0965254X.2012.752399.

Ulaga, Wolfgang and Andreas Eggert. 2006. "Value-Based Differentiation in Business Relationships: Gaining and Sustaining Key Supplier Status.” Journal of Marketing 70 (1):119_ 136. doi:10.1509/jmkg.2006.70.1.119.

Williams, Larry J., Nathan Hartman, and Flavia Cavazotte. 2010. "Method Variance and Marker Variables: A Review and Comprehensive CFA Marker Technique." Organizational Research Methods 13 (3):477-514. doi:10.1177/1094428110366036.

Workman Jr., John P., Christian Homburg, and Ove Jensen. 2003. "Intraorganizational Determinants of Key Account Effectiveness." Journal of Academy of Marketing Science 31 (1):3-21. doi:10.1177/0092070302238599.

$\mathrm{Wu}$, Chia-Huei, Sharon Parker, Long-Zeng Wu, and Cynthia Lee. 2018. "When and Why People Engage in Different Forms of Proactive Behavior: Interactive Effects of SelfConstruals and Work Characteristics." Academy of Management Journal 61 (1):293-323. doi:10.5465/amj.2013.1064.

Yang, Kejian, Xiaofei Yan, Jieyi Fan, and Zhengxue Luo. 2017. "Leader-Follower Congruence in Proactive Personality and Work Engagement: A Polynominal Regression Analysis." Personality and Individual Differences 105:43-46. doi:10.1016/j.paid.2016.09.033.

Yen, Dorothy A., and Bradley R. Barnes. 2011. "Analyzing Stage and Duration of Anglo-Chinese Business-to-Business Relationships." Industrial Marketing Management 40 (3):346-357. doi:10.1016/j.indmarman.2010.09.014.

Zhang, Zhen, Mo Wang, and Junqi Shi. 2012. "Leader-Follower Congruence in Proactive Personality and Work Outcomes: The Mediating Role of Leader-Member Exchange." Academy of Management Journal 55 (1):111-130. doi:10.5465/ amj.2009.0865.

Zhou, Yu, Ying Hong, and Jun Liu. 2013. "Internal Commitment or External Collaboration? The Impact of Human Resource Management Systems on Firm Innovation and Performance." Human Resource Management 52 (2):263-288. doi:10.1002/hrm. 21527. 